\title{
HABEAS CORPUS REVIEW OF MILITARY "GROSS SENTENCE" USAGE*
}

THE only form of sentence used in military law is a single sentence imposed in gross to cover all offenses of which the accused has been convicted. ${ }^{1}$ In civilian law, on the other hand, the better practice in multiple-offense cases ${ }^{2}$

*De Coster v. Madigan, 223 F.2d 906 (7th Cir. 1955).

1. "[U] sage has established that the sentence of a court-martial shall be, in every case, an entircty... covering all the charges and specifications upon which the accused is found guilty, however separate and distinct may be the punishments called for by the offenses." Winthrop, Miflitary Law and Precepents $\$ 615$ (2d ed. 1920). This usage persists unchanged in military law today. United States v. Horst, 1 U.S.C.M.A. 452, 4 C.M.R. 44 (1952); United States v. Keith, 1 U.S.C.M.A. 442, 4 C.M.R. 34 (1952); United States v. Gephart, 4 C.M.R. 306 (1952). See also Aycock \& Wurfel, Mil.itary Law Under the Unironar CoDe of Military Justice 165 (1955). It has been traditionally acknowledged by civilian courts as the only authorized form of military sentence. E.g., Carter v. McClaughry, 183 U.S. 365, 393 (1902) ; McDonald v. Lee, 217 F.2d 619, 622 (5th Cir. 1954).

Gross sentence usage is the result of military exigency. There is no time in the military for the luxury of separate trials. Consequently, all charges and specifications against an accused, even if unrelated, must be charged and adjudicated in one proceeding. See United States v. Keith, supra, at 448, 4 C.M.R. at 40; Winthrop, op. cit. supra, \$220; cf. Uniform Code of Military Justice art. 30, 64 STAT. 118 (1950), 50 U.S.C. $\$ 601$ (1952); Manual for Courts-Martial, United States II 26, 30 (1951) (hereinafter cited as U.S. Courts-Martial Manual). The military gross sentence usage recognizes the inadequacy of the lay court-martial to cope with technical problems of concurrent and consecutive sentencing-problems made more difficult by the unlimited joinder required in military law.

2. A military-type gross sentence, covering distinct and unrelated offenses, has been virtually precluded by civilian law's far more limited joinder. When multiple counts are joined in a civilian indictment, they must necessarily arise out of the same or closely related offenses. See, e.g., FED. R. CRIM. P. 7(c), S(a), 14; if. Claassen v. United States, 142 U.S. 140 (1891) ; United States v. Perplies, 165 F.2d 874 (7th Cir. 1948). Consequent$\mathrm{ly}$, it is often difficult to assess whether the counts actually constitute separate grounds for sentencing. And, although the court can impose cumulative sentences for each count of an indictment if the proof necessary to support each count is different, Blockburger v. United States, 284 U.S. 299, 304 (1932), appellate courts will reverse a separate sentence imposed un an "included" count if the requisite difference in the elements of proof is lacking. E.g., Wilson v. United States, 145 F.2d 734 (9th Cir. 1945) ; Barnes v. United States, 142 F.2d 648 (9th Cir. 1944).

Though recognizing that imposition of a separate sentence on each count is the better practice, most federal courts state that a "general sentence" covering several counts is valid if it does not exceed the aggregate which could have been pronounced on the counts individually. And if some of the counts are invalidated upon review, the sentence will be sustained if the remaining "good" counts will support it. Levine v. Hudspeth, 127 F.2d 982, 984 (10th Cir.), cert. denied, 317 U.S. 628 (1942) ; McKee v. Johnston, 109 F.2d 273, 275-76 (9th Cir. 1939) ; Jones v. Hill, 71 F.2d 932 (3d Cir. 1934). However, some recent cases have severely criticized the "general sentence" usage. E.g., Laing v. United States, 145 F.2d 111, 112 (6th Cir. 1944); Moss v. United States, 132 F.2d 875, 878 (6th Cir. 1943). See United States v. Keith, 1 U.S.C.M.A. 442, + C.M.R. 34 (1952), for an ex- 
is for the court initially to impose separate sentences for each conviction; ${ }^{3}$ the sentences are then merged to run concurrently, consecutively or both. ${ }^{4}$ Since most civilian appellate courts do not review the propriety of a sentence, "separate sentencing for each conviction provides an invaluable yardstick for adjustment of merged sentences when, on appeal, one or more of the convictions are invalidated. ${ }^{6}$ When one or more court-martial convictions are invalidated, military review authorities have no similar yardsticks. ${ }^{7}$ Unlike their civilian counterparts, however, military authorities are directed to consider the propriety as well as the legality of the sentence. ${ }^{8}$ And since gross sentence usage

cellent analysis by the Court of Military Appeals of the relationship between civilian multiple-count sentencing and the military gross sentence usage.

At the state level, where the counts allege the same general offense, it is common practice to impose a single sentence on the most "aggravated" count, and the prosecution either expressly or tacitly withdraws the other counts. People v. Bailey, 391 Ill. 149, 62 N.E.2d 796 (1945) ; People v. Giacomino, 347 Ill. 523, 180 N.E. 437 (1932) ; cf. State v. Stennett, 220 Iowa 388,260 N.W. 732 (1935). But it is recognized that, where the counts actually allege separate offenses, the proper rule is to impose a specific sentence under each count. People v. Player, 377 Ill. 417, 36 N.E.2d 729 (1941) ; People v. Elliott, 272 Ill. 592, 112 N.E. 300 (1916) ; State v. Cianci, 18 N.J. 191, 113 A.2d 176 (1955). But see Simmons v. State, 151 Fla. 778, 10 So. 2d 436 (1942).

3. See Laing v. United States, supra note 2, at 112; Moss v. United States, supra note 2, at 878; People v. Player, sntpra note 2, at 423,36 N.E.2d at 732 .

4. In the absence of explicit provision by the sentencing judge, sentences imposed on several counts or indictments consolidated for trial will run concurrently. If permitted by statute, the sentences may be made consecutive, but only if this intention is made explicit and the sequence intended is set out. See United States v. Daugherty, 269 U.S. 360, 362-64 (1926) ; cf. Hode v. Sanford, 101 F.2d 290 (5th Cir. 1939); McNealy v. Johnston, 100 F.2d 280 (9th Cir. 1938). See Orfield, Criminal Procedure From Arrest to Appeal $575-79$ (1947); ALI Code of Criminal Procedure, Commentary to $\$ 402$ at 1111 (1930).

5. Federal appellate courts have held themselves powerless to upset the judge's sentencing discretion. E.g., Beckett v. United States, 84 F.2d 731, 733 (6th Cir. 1936) ; Gurera v. United States, 40 F.2d 338, 340-41 (8th Cir. 1930). Reduction of inappropriate sentences must be left to the Federal Parole System and executive clemency. Cf. Chandler, LatterDay Procedures in the Sentencing and Treatment of Offenders in the Federal Courts, 37 VA. L. REv. 825 (1951). The discrepancies between sentences imposed for similar offenses have led to criticism advocating appellate review of their propriety. Sobeloff, The Sentence of the Court: Should There Be Appellate Review?, 41 A.B.A.J. 13 (1955).

Reduction of excessive sentences is authorized by statute in several states. See Dession, Crrnimal Law Admintstration and Public Order 992 n.1 (1948) (collecting citations); Hall, Criminal Sentence On Appeal, 37 Colum. L. Rev. 521, 762 (1937).

6. Blitz v. United States, 153 U.S. 308, 317-18 (1894) ; cf. In re Wright, 51 F. Supp. 639 (N.D. Cal. 1942).

The civilian appellate court may also remand to the trial court for resentence on the affirmed convictions. E.g., Moss v. United States, 132 F.2d 875, 878 (6th Cir. 1943) ; State v. Cianci, 18 N.J. 191, 113 A.2d 176 (1955). This practice is not feasible in military law. See notes 44-45 infra and accompanying text.

7. The military review authorities do have at their disposal a "Table of Maximum Punishments" which states the maximum sentence permissible for each offense. U.S. Courts-Martial Manual $\{127 c$. See notes 15,40 infra.

8. "[T] he convening authority [i.e., the local military commanding officer] shall approve only such findings of guilty, and the sentence or such part or amount of the sentence, 
presumes that any sentence imposed in a multiple-conviction military case covers all the convictions returned, it is standard procedure for the board of review to remit that portion of the gross sentence which appears excessive in relation to the convictions affirmed. ${ }^{9}$

The recent case of De Coster $v$. Madigan ${ }^{10}$ casts doubt upon the validity of the gross sentence usage. A general court-martial had convicted De Coster of the attempted rape and murder of a Korean woman. ${ }^{11}$ The law officer then

as he finds correct in law and fact and as he in his discretion determines should be approved." Uniform Code of Military Justice art. 64, 64 STAT. 128 (1950), 50 U.S.C. $\$ 651$ (1952).

"[The board of review] ... shall affirm only such findings of guilty, and the sentence or such part or amount of the sentence, as it finds correct in law and fact and determines, on the basis of the entire record, should be approved." Uniform Code of Military Justice art. 66(c), 64 STAT. 128 (1950), 50 U.S.C. \$ 653 (c) (1952).

The military review hierarchy has been highly praised for its use of this flexible sentence-adjustment procedure to achieve just and uniform results. See Aycock \& Wurfer, op. cit. supra note 1, at 154-58, 165-67; Currier \& Kent, The Boards of Review of the Armed Services, 6 VAnd. L. Rev. 241 (1953) ; Feld, The Court-Martial Sentence: Fair or Foull, 39 VA. L. Rev. 319 (1953). But see Keeffe \& Moskin, Codified Military Injustice, 35 CORNELK L.Q. 151 (1949).

9. E.g., United States v. Horst, 1 U.S.C.M.A. 452, 4 C.M.R. 44 (1952) ; United States v. Gephart, 4 C.M.R. 306, petition denied, 2 U.S.C.M.A. 670, 5 C.M.R. 130 (1952); see United States v. Lanford, 6 U.S.C.M.A. 371, 376, 20 C.M.R. 87, 92 (1955) (dictum).

For years the boards of review followed the federal court presumption of the "good" sentence for the good count, see note 2 supra, and allowed the sentence originally imposed to stand, notwithstanding the fact that several convictions had been invalidated, if the original sentence did not exceed the maximum permissible for the remaining counts affirmed. But since United States v. Keith, 1 U.S.C.M.A. 442, 4 C.M.R. 34 (1952), the Court of Military Appeals has stated that it would remand to the board all cases in which it had affirmed some but not all convictions, even if the remaining convictions legally sustained the original gross sentence, in order to insure that the sentence was appropriate as well as legal. Where the sentence is not legally excessive, however, there is no requirement that the boards must grant nominal reductions on remand. See United States v. Battle, 10 C.M.R. 313 (1953), petition denied, 4 U.S.C.M.A. 721, 11 C.M.R. 248 (1954); United States v. Barfield, 6 C.M.R. 318 (1952), petition denied, 2 U.S.C.M.A. 694, 9 C.M.R. 139 (1953) ; United States v. Patrick, 5 C.M.R. 288 (1952); United States v. Keith, 5 C.M.R. 165, further review of 1 U.S.C.M.A. 442, 4 C.M.R. 34 (1952); cf. Axcock \& WURFEL, op. cit. supra note 1, at 165-67.

10. 223 F.2d 905 (7th Cir. 1955).

The government will not seek a writ of certiorari on the De Coster decision. Letter from Oscar H. Davis, First Assistant to the Solicitor General of the United States, to the Yalc Law Journal, Dec. 22, 1955, on file in Yale Law Library. However, in the companion case of Jackson v. Humphrey, Habeas Corpus No. 282, M.D. Pa., Nov. 25, 1955 , the court rejected a petition for habeas corpus based upon the same circumstances involved in the De Coster case. Counsel in the Jackson case plans to appeal to the Third Circuit, and intends to seek certiorari if the Third Circuit affirms. Letter from Urban P. Van Susteren, counsel for both Jackson and De Coster, to the Yale Law Journal, Dec. 22,1955 , on file in Yale Law Library.

11. United States v. Fowler, Court Martial No. 347258 (June 9, 1951). Two accessories were convicted with De Coster. Defendants admitted that they had taken a Korean voman from her home and attempted to rape her. Though the woman was later found dead, a gunshot wound in her head, defendants alleged that they had fled, leaving the woman unharmed, after exchanging shots with Korean rescuers. 
gave sentencing instructions to the court-martial on the murder conviction alone. The court-martial sentenced De Coster to life imprisonment, the minimum sentence permissible for that count. ${ }^{12}$ On appeal, ${ }^{13}$ the board of review invalidated the murder conviction, but upheld the conviction for attempted rape and reduced the sentence to twenty years. ${ }^{14}$ This was the maximum sentence permissible for attempted rape. ${ }^{15}$

The Seventh Circuit held the board's twenty year sentence void as a sentence de novo, and issued a writ of habeas corpus ordering De Coster's release from custody. ${ }^{16}$ The court concluded that the court-martial sentence had not been imposed "in gross," but had been wholly imposed on the murder conviction alone. ${ }^{17}$ The court supported this conclusion on dual grounds: that no sentencing instructions had been given to the court-martial on the attempted rape conviction, and that the sentence imposed by the court-martial was the mandatory minimum for the murder conviction alone. ${ }^{18}$ Once the murder conviction was invalidated, the court reasoned, the entire punishment became excessive. ${ }^{19}$ Accordingly, the board of review had not "merely remitted" the

12. Articles of War art. 92, 41 Stat. 805 (1920), as amended (now Uniform Code of Military Justice art. 118, 64 STAT. 140 (1950), 50 U.S.C. $\$ 712$ (1952)).

The full sentence imposed was dishonorable discharge, total forfeiture of pay and allowances and confinement at hard labor for life. Dishonorable discharge and total forfeiture must be adjudged with a sentence of life imprisonment. U.S. Courts-Martur MLANUal If 126a. Hard labor is optional but usual for sentences of confinement. See Uniform Code of Military Justice art. 58, 64 STAT. 126 (1950), 50 U.S.C. $\$ 639$ (1952) ; U.S. CourTsMartial Manual II 126j; United States v. Kinder, 14 C.M.R. 742, 785, petition denied, 4 U.S.C.M.A. 745 (1954).

13. The substantive offenses with which plaintiff was charged were governed by the Articles of War, see note 12 supra, but the procedures for review of his sentence were those established by the new Uniform Code. See De Coster v. Madigan, 223 F.2d 906, 908 (7th Cir. 1955).

14. The murder conviction was invalidated for insufficiency of evidence showing that the deceased had been shot by one of the accused. But the board found that beyond a reasonable doubt, "the crime of attempted rape (if not rape)" had been committed. United States v. Fowler, 2 C.M.R. 336, 342, petition denied, 1 U.S.C.M.A. 713, 3 C.M.R. 151 (1952).

15. Articles of War art. 96, 41 Srat. 806 (1920) (now Uniform Code of Military Justice art. 134, 64 Stat. 142 (1950), 50 U.S.C. $\$ 728$ (1952)).

See U.S. Courts-Martial Manual $\Uparrow 127 c$ ("Table of Maximum Punishments").

16. De Coster v. Madigan, 223 F.2d 906, 911 (7th Cir. 1955).

17. Id. at 910 .

18. "Of course, any suggestion that the court-martial should have sentenced plaintiff for a term of life plus twenty years would be ridiculous, but equally so is the assertion that the court-martial did or intended to impose any part of its sentence for attempted rape. It lacked even the necessary instructions upon which such award of punishment would have to be based." Ibid.

The Seventh Circuit itself seemed to indicate that De Coster should be quite strictly limited to "the curious combination of circumstances involved in this case. ..." Id. at 909 . While the limiting factors seem irrelevant to the court's conclusions, which are predicated upon broader grounds, see notes 24-34, 46-47 infra and accompanying text, there is no apparent reason to extend the case beyond its immediate factual situation.

19. De Coster v. Madigan, 223 F.2d 906, 910 (7th Cir. 1955). 
excessive portion of a gross sentence, but had imposed on its own motion a twenty year sentence for attempted rape. ${ }^{20}$ Since only a court-martial is empowered to impose sentence, and the board is authorized only to reduce a sentence validly imposed, ${ }^{21}$ the court held that the board's sentence was void for lack of jurisdiction. ${ }^{22}$ The court believed that the most the board could have done was remand to the court-martial for sentencing. ${ }^{23}$

It is impossible to justify the court's conclusion that the court-martial had never intended or authorized a sentence "in gross." The accepted military usage is that a mandatory sentence imposed in a multiple-conviction case covers all the convictions. ${ }^{24}$ And the irrefutable fact is that De Coster was convicted of both murder and attempted rape. ${ }^{25}$ True, the court-martial sentence was the minimum permissible for the murder charge alone. ${ }^{26}$ But, short of the death penalty, the court-martial could not have imposed a greater sentence upon De Coster no matter how many offenses he was convicted of, and no matter how reprehensible they were. ${ }^{27}$ Moreover, the omission of sentencing instructions on the attempted rape conviction has no relevance. It did not divest the court-

\section{Ibid.}

21. Ibid.

22. "This action of imposing sentence was beyond the Board's authority because the statute grants it no such power. 50 U.S.C.A. § 653, U.C.M.J. art. 66." De Coster v. Madigan, 223 F.2d 906, 910 (7th Cir. 1955).

23. Id. at 911 .

But if the court's theory of the case is correct, it is by no means clear that sentence could have been imposed upon remand. If the original sentence was not in gross, then the court-martial in its discretion must have decided not to impose a penalty for the attempted rape. And the Uniform Code specifically states that upon rehearing "no sentence in excess of or more severe than the original sentence shall be imposed. .." Uniform Code of Military Justice art. 63, 64 SrAT. 127 (1950), 50 U.S.C. $\$ 650$ (1952). The Code also provides that the record may be returned where there is an apparent error or omission, or where the record shows improper or inconsistent action with regard to findings or sentence, but it explicitly cautions that in no case may the record be returned to increase the severity of the sentence unless the sentence prescribed for the offense is mandatory. Uniform Code of Military Justice art. 62, 64 StAT. 127 (1950), 50 U.S.C. $\S 649$ (1952); cf. United States v. Long, 4 U.S.C.M.A. 101, 15 C.M.R. 101 (1954).

24. In United States v. Gephart, 4 C.M.R. 306, petition denied, 2 U.S.C.M.A. 670, 5 C.M.R. 130 (1952), Gephart, convicted of murder, robbery and absence without leave, was sentenced to life imprisonment, the mandatory minimum for murder alone. The murder conviction was invalidated by the convening authority. The board of review held that the original sentence was legally in gross, since Gephart had been convicted of all three offenses, so that reduction or approval of the single sentence on review would not be an original sentence for convictions not considered by the court-martial. The Court of Military Appeals denied the petition for further review. See also Frazier v. Anderson, 2 F.2d 36, 38 (8th Cir. 1924) (dictum); cases cited note 1 supra.

The only mandatory sentences remaining in military law today are death and life imprisonment. See Uniform Code of Mrilitary Justice arts. 106, 118, 64 Stat. 136, 140 (1950), 50 U.S.C. $\$ \$ 700,712$ (1952).

25. See note 11 supra and accompanying text.

26. See notes 12,18 supra.

27. See U.S. Courts-Martial Manual app. 13 ("Forms of Sentences"). 
martial of sentencing jurisdiction, nor in any way prejudice the accused. ${ }^{28}$ The Uniform Code and the Courts-Martial Manual make it clear that, once the accused has been duly convicted, sentencing instructions are not prerequisite to valid imposition of sentence. ${ }^{29}$ They are discretionary with the law officer. And the discretion exercised in De Coster could not have been prejudicial : ${ }^{30}$ the identical sentence would necessarily have been imposed with or without the omitted instructions. ${ }^{31}$

The actual basis for the grant of habeas corpus must have been the "unfairness" of the gross sentence usage itself. Gross sentence usage ${ }^{32}$ would have permitted the board of review in the De Coster case to have imposed the maximum sentence permissible for the attempted rape conviction without having received any indication of what the court-martial would have imposed if it had considered that conviction alone. ${ }^{33}$ And the Seventh Circuit believed it unfair for a tribunal other than the trial forum to impose this sentence on De Coster because, had the board remanded the attempted rape conviction, the court-martial might have imposed a far less severe sentence which the board could not have increased upon review. ${ }^{34}$

28. The Uniform Code of Military Justice art. 59, 64 STAT. 127 (1950), 50 U.S.C. $\$ 646$ (1952), states: "A finding or sentence of a court-martial shall not be held incorrect on the grounds of an error of law unless the error materially prejudices the substantive rights of the accused." Cf. United States v. Jones, 1 U.S.C.M.A. 302, 304, 3 C.M.R. 36, 38 (1952).

29. U.S. Courts-Martial Manual $\{73 c$ specifically states that the law officer is not required to give the court-martial any instructions other than those required by article 51(c) of the Uniform Code. Article 51(c) provides: "Before a vote is taken on the findings, the law officer ... shall, in the presence of the accused and counsel, instruct the court as to the elements of the offense. ..." (Emphasis added.) Uniform Code of Military Justice art. 51 (c), 64 STAT. 124 (1950), 50 U.S.C. $\$ 626$ (c) (1952). The only provision on sentencing instructions is found in U.S. Courts-MarTial Manual $\llbracket 76 b(1)$ : "Before a general court-martial closes to deliberate and vote on the sentence, the law officer may advise it of the maximum punishment which may be adjudged for each of the offenses of which the accused has been found guilty." (Emphasis added.)

30. Even where the law officer has affirmatively prejudiced the accused by giving faulty sentencing instructions, such prejudice is curable upon review. E.g., United States v. Williams, 4 U.S.C.M.A. 69, 15 C.M.R. 69 (1954); United States v. Crusoe, 3 U.S.C. M.A. 793, 14 C.M.R. 211 (1954); United States v. Traska, 15 C.M.R. 559 (1954) ; AxCOCK \& WURFEL, op. cit. supra note 1, at 167. But see United States v. Cooper, 2 U.S.C. M.A. 333, 8 C.M.R. 133 (1953) (semble).

31. See notes 24-27 supra and accompanying text.

32. I.e., the presumption that any sentence imposed in a multiple-conviction case covers all the convictions involved. See note 1 supra.

33. See notes 20,22 supra and accompanying text.

34. De Coster v. Madigan, 223 F.2d 906, 910 (7th Cir. 1955).

"Neither the convening authority nor any other officer is authorized to add to the punishment imposed by a court-martial." U.S. Courts-Martial Manual If $88 a$. See also Uniform Code of Military Justice art. 66, 64 Srat. 128 (1950), 50 U.S.C. $\$ 653$ (1952) ; U.S. CourTsMartial Manual $\{100 a ; c f$. United States v. Lanford, 6 U.S.C.M.A. 371, 382, 20 C.M.R. 87, 98 (1955). 
The court failed to consider that, in practice, courts-martial perform a function nearer to that of a jury than a court. Courts-martial are composed of laymen. ${ }^{35}$ Although they theoretically can impose whatever sentence they deem fit, in the great majority of single-conviction cases they actually impose the maximum sentence permissible. ${ }^{36}$ The final sentence is set upon review by the legally-trained board. ${ }^{37}$ Congress expressly empowered and required the board to "affirm only such findings of guilt, and the sentence or such part or amount of the sentence as it finds correct in law and fact" and appropriate on the basis of the entire record. ${ }^{38}$ This power was granted for the express purpose of promoting uniformity of sentences throughout the services. ${ }^{39}$ It has been consis-

35. See Uniform Code of Military Justice art. 25, 64 STAT. 116 (1950), 50 U.S.C. $\$ 589$ (1952). A few states allow juries to impose sentence. However, legal scholars and judges in those jurisdictions have severely criticized the vesting of a sentencing function in a lay body. See, generally, Orfield, Criminar Procedure From Arrest to Appeal 537 n. 45 (1947), and authorities there cited.

36. Report of the General Court-Martial Sentence Review Board to the SecreTARX OF THE NAvY, § VII(1) (B), at 191-94 (1947), cited in Keeffe \& Moskin, Codified Military Injustice, 35 CoRNell L.Q. 151, 162 (1949). But see Uniform Code of Military Justice art. 18, 64 Stat. 114 (1950), 50 U.S.C. $\$ 578$ (1952); U.S. Courts-Martial MAnUal $\{76 a$.

37. See United States v. Gephart, 4 C.M.R. 306, petition denied, 2 U.S.C.M.A. 670, 5 C.M.R. 130 (1952), discussed in note 24 supra (board of review found life imprisonment legally permissible but reduced the sentence to twenty-five years for appropriateness); Testimony of Edmund M. Morgan, Professor of Law, Vanderbilt University, Hearings Before a Subcomnittee of the Senate Committee on Armed Services on S. 857 and H.R. 4080, S1st Cong., 1st Sess. 42 (1949) ; Feld, The Court-lMartial Sentence: Fair or Foul?, 39 VA. L. Rev. 319, 329-31 (1953) ; Keeffe \& Moskin, supra note 36, at 162.

38. Uniform Code of Military Justice art. 66(c), 64 Stat. 128 (1950), 50 U.S.C. $\$ 653$ (c) (1952). (Emphasis added.)

39. The draftsmen of the Code placed great faith in the article 66(c) procedure. "The Board may set aside, on the basis of the record, any part of a sentence, either because it is illegal or because it is inappropriate. It is contemplated that this power will be exercised to establish uniformity of sentences throughout the armed forces." S. REP. No. 486, 81st Cong., 1st Sess. 28 (1949) ; H.R. Rep. No. 491, 81st Cong., 1st Sèss. 31-32 (1949) ; cf. Currier \& Kent, The Boards of Review of the Armed Services, 6 VAND. L. REv. 241 (1953).

Article $66(\mathrm{c})$ was enacted despite the testimony of career soldiers and the Judge Advocates General to the effect that it gave too much discretion to lawyers inexperienced in the demands of "command discipline." See Hearings Before a Subcommittee of the Senate Committee on Armed Services on S. 857 and H.R. 4080, 81st Cong., 1st Sess. 220-40, 258-59, 285 (1949).

Proponents of "command discipline" are still critical of military review procedures. See Jornt Annual Reports 1.954, filed by the Court of Military Appeals, Judge Advocates General of the Armed Forces, and General Counsel of the Treasury Department pursuant to Uniform Code of Military Justice art. $67(\mathrm{~g}), 64$ StaT. 129 (1950), 50 U.S.C. $\$ 654(\mathrm{~g})$ (1952). One proposal would abrogate the board's power to reduce sentences for inappropriateness. Id. at 38. The Court of Military Appeals refused to join in sponsoring any of the recommendations made in the JorNT ANNUAL REPORTS 1954 "because of a belief that either the need for them has not been demonstrated or they turn back the wheels of progress and destroy some of the substantial rights granted by Congress to members of the Armed Forces." Id. at 14 . 
tently invoked to achieve uniform results in situations like $D e$ Coster, where the original sentence exceeded the legal maximum for the remaining convictions after some had been invalidated. ${ }^{40}$ The gross sentence usage has afforded the flexibility that execution of the congressional plan requires. ${ }^{41}$

And there has been no resulting injustice. The board is far more comparable to the civilian sentencing judge than is the inexpert court-martial. ${ }^{42}$ Board members are better equipped to decide whether a penalty is "appropriate" because of their legal training and greater over-all knowledge of uniform interservice sentencing. It is true that board members are not present at trial, but this is largely cured by detailed pre-sentencing reports sent up to the board along with the trial record. ${ }^{43}$ Moreover, it cannot be cured by remand to the original court-martial: ${ }^{44}$ such remand is seldom administratively feasible because the court-martial to which the case would be remanded would almost never be the same one that convicted defendant in the first place. ${ }^{45}$

40. See authorities cited note 9 supra; United States v. Goodwin, 5 U.S.C.M.A. 647, 657,18 C.M.R. 271, 280 (1955) (dictum).

41. It is not only unrealistic to require a lay court-martial to handle the complex: problems of cumulative and consecutive sentencing for separate, joined counts, see notes 1-9 supra, but such a procedure would also severely restrict the discretionary flexibility of the boards. Separate sentences on each conviction could be decreased if excessive, see note 38 supra, but could not be increased if insufficient, see note 34 supra. And it seems likely that the court-martial, required to impose sentence on many convictions, might impose separate sentences which, though appropriate in the aggregate, would often be inappropriately low on any single conviction. And if this occurred, the board's hands would be tied if one or more convictions were invalidated.

42. Boards of review are "each composed of not less than three officers or civilians, each of whom shall be a member of the bar of a Federal court, or of the highest court of a State of the United States." Uniform Code of Military Justice art. 66(a), 64 Srst. 128 (1950), 50 U.S.C. $\$ 653$ (a) (1952). See Currier \& Kent, supra note 39.

43. "The report is much like a probation report to a sentencing judge in civilian law, in that it includes information on the civilian and military background of the accused as well as the circumstances surrounding the offense itself as disclosed in the record of trial." Feld, supra note 37, at 328; cf. U.S. Courts-Martial Manual $\{$ 89. The Court of Military Appeals has stated that the boards of review can and should consider such supplementary material for purposes of evaluating the propriety of the sentence. United States v. Lanford, 6 U.S.C.M.A. 371, 379-80, 20 C.M.R. 87, 95 (1955). See also United States จ. Cavallaro, 3 U.S.C.M.A. 653, 656, 14 C.M.R. 71, 74 (1954); United States v. Crusoe, 3 U.S.C.M.A. 793, 797, 14 C.M.R. 211, 215 (1954).

44. See note 23 supra. The Uniform Code provides that the convening anthority may return the record to the original court-martial for reconsideration and revision, if the record is inconsistent with the sentence. Uniform Code of Military Justice art. 62, 64 Srar. 127 (1950), 50 U.S.C. $\S 649$ (1952) ; cf. U.S. Courts-Martial. Manual If \$o. However, the Uniform Code provides that remanded hearings and new trials shall take place before a court-martial composed of persons not members of the court-martial which first tried the accused. Uniform Code of Military Justice art. 63, 64 SrAT. 127 (1950), 50 U.S.C. $\$ 650$ (1952); cf. U.S. Courts-Martial Manual Ift 81, 92.

45. "In a military situation [remand to the trial forum for resentencing] . . . is impracticable, if not impossible of achievement. In view of the lapse of time involved, it is highly probable that the court-martial which tried the accused ... is no longer functioning as such. Through change of assignment, or otherwise, its members, indeed, may be scat- 
De Coster conflicts with military law and military practice. The objections it raises to gross sentence usage and board of review sentence adjustment are fundamental. The court's objections would make it impossible for the board to reduce a gross sentence to an amount it finds appropriate to the convictions affirmed, whenever the sentence originally imposed on all convictions is less than the sum of maximum sentences permissible for each conviction involved. ${ }^{46}$ For it will never be certain just how the court-martial meant to apportion the original sentence. But the question of how the court-martial meant to apportion the sentence became relevant only because the Seventh Circuit chose to ignore the established principle that a court-martial sentence is imposed and reviewed as an entirety, ${ }^{47}$ and instead imported the separate-sentence procedure of civilian law into the military arena.

Within the present system of military law, the gross sentence usage is both fair and efficient. It recognizes and attempts to compensate for the fundamental inadequacies of the lay jury as a sentencing body. It complements the congressional policy of promoting a flexible sentence-adjustment procedure by which the legally-trained boards of review can apply sentences uniformly throughout the services. Civilian courts should not use the writ of habeas corpus as a means by which to bring this aspect of military law into conformity with their own concepts of civilian justice. ${ }^{48}$

tered beyond recall .... Remand to the trial forum, for virtually any purpose in the military scene, is a difficult business. . . Fortunately, it is also an unnecessary one." United States v. Keith, 1 U.S.C.M.A. 442, 451, 4 C.M.R. 34, 43 (1952); cf. United States v. Jones, 1. U.S.C.M.A. 302, 304, 3 C.M.R. 36, 38 (1952).

46. "The real basis of appellate defense counsel's argument is that the convening authority's action was speculative, since it was impossible for him to know what sentence the court would have adjudged had it considered only the findings of guilty, as approved. This same objection would apply with equal force to the situation wherein an accused is found guilty of any offense but the convening authority approves only the findings of guilty of a lesser included offense and approves a lesser sentence. Under defense's theory, this, too, would be a speculative sentence.

"We have carefully examined both the Uniform Code and the Manual and find no such limitation upon the powers of the convening authority as urged here. ... [F]or the convening authority can correct an illegal sentence by approving only so much of the sentence as is legal." United States v. Gephart, 4 C.M.R. 306, petition denied, 2 U.S.C.M.A. 670, 5 C.M.R. 130 (1952). And the powers of the boards are in every way on a par with those of the convening authority in this respect. See notes 8,24,37 supra; cf. United States v. Lanford, 6 U.S.C.M.A. 371, 20 C.M.R. 87 (1955).

47. Military authorities believe that "we cannot and should not speculate upon what sentence the trial court would have assessed if it had acquitted the accused of [charge 1] ... and convicted him of [charge 2] ... alone...." United States v. Keith, 5 C.M.R. 165, 166, further review of 1 U.S.C.M.A. 442, 4 C.M.R. 34 (1952) ; cf. United States v. Horst, 1 U.S.C.M.A. 452, 4 C.M.R. 44 (1952) ; United States v. Gephart, 4 C.M.R. 306, petition denied, 2 U.S.C.M.A. 670, 5 C.M.R. 130 (1952).

48. The Court of Military Appeals was established by Congress in order to interpret and apply the Uniform Code; its interpretations must be respected by civilian courts. See Burns v. Wilson, 346 U.S. 137, 140, 142, rehearing denied, 346 U.S. 844 (1953) ; Shaw v. United States, 209 F.2d 811, 812 (D.C. Cir. 1954); Uniform Code of Military Justice art. 
76, 64 STAT. 132 (1950), 50 U.S.C. $\$ 663$ (1952). The Court of Military Appeals has accepted, applied and broadly interpreted the gross sentence usage and the board of review procedure of article 66 (c). See notes $1,9,39,44$ supra.

In Burns v. Wilson, supra, the Supreme Court stated that in certain limited instances it would be proper for civilian habeas corpus review to determine whether the military tribunals had given full consideration to objections raised by the defendant on due process grounds. Id. at 142. The scope of the Burns $v$. Wilson dictum is uncertain. See Aycock \& Wurfel, Military Law Under the Uniform Code of Military Justice 365, 371, 337-78 (1955) ; Notes, 27 So. Calrf. L. Rev. 333 (1954), 39 A.B.A.J. 909 (1953). The best interpretation would seem to be that habeas corpus review is now permissible if there has been an abusive or unfair application of military usage and statutory procedures. See Notes, 52 Mich. L. Rev. 602, 27 Texple L.Q. 342 (1954) ; cf. Reaves v. Ainsworth, 219 U.S. 296 (1911). Certainly, however, it is impossible to interpret the Burns dictum as authority for a civilian attack, by writ of habeas corpus, on the fairness of the military procedures themselves. 